\title{
Assessment Techniques in Forest Biomass along the Timber Supply Chain
}

\author{
Heesung Woo ${ }^{1, *} \mathbb{D}$, Mauricio Acuna ${ }^{2} \mathbb{D}$, Seungwan Cho $^{1}$ and Joowon Park ${ }^{1, *(\mathbb{C}}$ \\ 1 School of Forest Sciences and Landscape Architecture, Kyungpook National University, 80 Daehak-ro \\ Buk-gu, Daegu 41566, Korea; one5639@naver.com \\ 2 Forest Industries Research Centre, University of the Sunshine Coast, Locked Bag 4, Maroochydore DC, \\ Queensland 4558, Australia; macuna@usc.edu.au \\ * Correspondence: whs1608@gmail.com (H.W.); jwnpark@gmail.com (J.P); Tel.: +82-10-4354-1608 (H.W.)
}

Received: 2 October 2019; Accepted: 8 November 2019; Published: 13 November 2019

\begin{abstract}
As a part of the renewable energy cycle, forest biomass resources are considered to be important renewable materials and energy sources in many countries. It is evident from international and local research into forest biomass utilization that several challenges must be addressed to ensure logging waste can be transformed into material of commercial value. Several logistical and supply chain challenges have already been identified, including uncertainty about the nature, amount, and quality of forest residues. In this context, this paper presents a summary review of estimation methods and techniques for managing forest and woody residue along the timber supply chain. The review examines both the opportunities and the challenges evident in the international forest residue estimation methods within each supply chain for primary and secondary forest resources. The review also discusses techniques for supply chain and management planning and highlights the limitations of existing information and communication technology (ICT) implemented for forest biomass research.
\end{abstract}

Keywords: forest biomass; biomass energy; supply chain; biomass estimation; assessment techniques; biomass feedstock

\section{Introduction}

Because of fossil fuel cost and environmental concerns, processed forest and woody biomass have become a valuable source of bioenergy and bio-based wood products; their production technologies are under continuous improvement. The European Union (EU) has announced that $20 \%$ of energy will be generated from renewable sources including bioenergy by 2020 [1]. In the 27 member nations of the EU, biomass contributed $8.2 \%$ of the EU's total energy consumption in 2010, nearly $64 \%$ of Europe's renewable energy [2]. Forest biomass is the dominant feedstock, contributing about two-thirds of the total biomass for energy production or about half of all renewable energy sources [3]. In the United States, biomass is one of the key energy contributors, having supplied approximately 2.9 quadrillion Btus in 2003 [4]. The current primary biomass comes from a wide range of forestry and agricultural sources such as harvesting residue, industrial processing residues, and municipal solid and urban wood residues [5].

In forestry, wood-based biomass sources include forest logging residue, plantation biomass feedstocks, processing residues, and municipal and urban wood residues [6,7]. Forest-sourced biomass can be categorized into one of three supply chain segments: primary, secondary, and tertiary. Primary forest biomass sources include conventional logging residue, thinning, and land clearing as well as fuel load materials removed from forestland. Processing mill residues, including primary and secondary mills, are the main secondary sources of forest biomass. The last segment of biomass sources along the 
forest biomass supply chain is urban wood residue; this includes construction and demolition wood debris, tree trimmings, packaging, and consumer waste [8].

Previous studies on biomass utilization were reviewed with a focus on supply chain models and the most productive [9-17] and cost-effective forest biomass recovery technologies [18,19]. To improve decision making in the biomass energy supply chain, the design, planning, and management of these supply chains have been reviewed by several researchers $[12,16,17]$. In addition, decision support models for the chains were discussed by Sharma et al. and Awudu and Zhang in [13,15]. Productive and cost-efficient technologies for forest biomass harvesting were analyzed by Mohammad et al. in North American, European, and Southern Hemisphere regions [18,19]. Most of these papers focused only on the forest harvesting techniques considered to be important in the design of the biomass energy supply chain; there are few review studies related to forest biomass estimation techniques along the timber supply chain $[4,8,20]$. Therefore, it is timely to review and analyze what has been done so far about these estimates. This paper compiles and review's state-of-the-art biomass supply chain technology to support the further industrial and academic development of sustainable forest biomass supply chains.

\section{Methodology}

The primary objective of the methodology was to support the production of this literature review on forest and woody biomass and biomass energy supply chain covering Australian and International literature primarily published in the last 20 years. This selective rather than systematic review of recent forest and woody biomass research highlights assessment techniques in forest biomass along the timber supply chain

It details the approach to scoping the focus of the study including inclusion/exclusion criteria; search terms; and the search strategies deployed to identify peer-reviewed publications, reports and other materials. In developing the methodological approach for undertaking this review, the following broad inclusion criteria were applied:

- Literature published in the form of full text articles. Literature published in the form of abstracts, full reports or reviews are only included where they offered a new or unique contribution to addressing the primary questions posed by authors;

- Literature published in the English language. Literature published in languages other than English have generally been excluded from this review;

- Literature published in Australia and internationally since the year 2000. Generally, literature published prior to 2000 (unless of particular relevance) has been excluded;

The aim of scoping the review in this manner was to ensure a broad coverage of the literature relevant to assessment techniques in forest biomass along the timber supply chain.

The search strategy used to undertake this review was primarily aimed at ensuring the identification of:

- Peer-reviewed publications providing quantitative and/or qualitative evidence on estimation methods and techniques for managing forest and woody residue along the timber supply chain.

- The review examines both the opportunities and the challenges evident in the international forest residue estimation methods within each supply chain for primary and secondary forest resources.

The formal search strategy targeted a number of sources of potential materials on biomass energy utilization including full text databases; web-based search engines and direct analysis of output from government agencies and centers of research excellence. The key databases searched to identify and collect original peer-reviewed publications and reviews Web of Science, SCOPUS. Additional publications were identified and collected following citation searching on the multiple databases available through European Standard and FAO. The key web-based search engine utilized was Google Scholar. The formal search strategy produced an initial list of more than 150 indexed published resources 
comprised of peer-reviewed papers, international standards and reports. Following examination of these materials for suitability and fit 105 publications full text papers were analyzed for consideration to be included in the review.

\section{Primary Forest Resources}

\subsection{Logging Residues}

The main source of forest biomass varies over different parts of the world. European countries utilize wood from thinning operations as well as harvesting residues from clear-cuts [21]. From an economic perspective, biomass recovery from thinning is more costly than residue utilization because thinning operations bear the entire operating cost, while clear-cut residue carries only the chipping and secondary transportation costs [22]. Kizha and Han (2016) evaluated the sorting of forest harvest residues by quality class at their landing sites to increase forest product yields. Sorting residue into chipping or grinding categories can increase biomass product quality but leads to higher operating costs [23]. In the Southern Hemisphere and the Southern USA, the main source of bioenergy comes from clear-cut residues, although in the Southern USA, some stemwood is also used for this purpose [19].

Logging residue is one of the primary sources of forest biomass and is typically generated by operations such as commercial timber harvest, fire hazard reduction thinning, salvage logging, forest restoration, and pre-commercial thinning [24]. Harvesting residue, thinning residue, and biomass residue are all terms associated with logging residue. EN ISO 16559 (Solid biofuels Terminology, definitions and descriptions) defines logging residue as woody biomass created during wood harvesting.

Among forest biomass utilization options (e.g., energy tree plantation, direct use of trees as fuel, and residue collection), logging residue is the only source considered to be carbon-neutral [25-29]. Internationally, forest residues are widely used to produce valuable bioenergy and bio-based products. A detailed understanding of the availability, quality, and feasibility of residue utilization requires high-quality information about forestry supply chains, their management, and their operation. Residue utilization remains limited; there is a lack of clarity on how to address the factors inhibiting its development. A cost-efficient design for the forest biomass supply chain may overcome these challenges. Quantitative techniques can aid decision-makers in balancing the economic, environmental and social factors in these supply chains [9,30-32].

From international and local research into residue utilization, it is evident that several challenges must be addressed to ensure logging residues can be transformed from a waste material into a product having commercial value. Some logistical and supply chain challenges have already been identified:

- $\quad$ Forest residues are highly varied, can be of low quality, and are widely distributed across timber harvesting sites. All these factors impose residue collection, processing, and transportation challenges with implications for the economic viability of residue utilization operations.

- While large volumes of residue exist, there is uncertainty about the nature, amount, and quality of residues in any particular harvesting operation.

- There is limited knowledge about other factors, such as forest site accessibility throughout the year, weather conditions, availability of pre-processing technology, haulage contracting models, and distance to market.

In practical biomass planning, a quantitative estimate of the available amount of logging residue is critical to the prediction of a biomass supply chain's financial feasibility and potential revenue [24]. Several logging residue estimation methods have been investigated and used in biomass pre-feasibility research. These techniques have been applied to a variety of forest types and levels of planning.

\subsubsection{Remote Sensing}

At the state and national levels of biomass estimation, geographic information systems (GIS), remote sensing, and yield growth model approaches have been preferred [33-35]. Remote sensing 
data and techniques have become important to biomass estimation. Biomass estimation from remote sensing data has been described in $\mathrm{Lu}$ and Patenaude [36,37]. The relationship between spectral response and biomass is investigated using multiple regression analysis and k-nearest neighbor as well as other neural network learning techniques.

Additionally, indirect relationships estimated from remote sensing data like leaf area index (LAI) and structure (crown closure) have been used to develop models to estimate biomass [38-41]. Labrecque et al. [42] assessed four different approaches for the use of remote sensing data to investigate its benefit for estimating above-ground biomass (AGB). This study revealed that the selection of the method was depend on the data's level of precision and availability.

There are multiple data sources such as the Advanced Very High Resolution Radiometer (AVHRR) and Moderate Resolution Imaging Spectroradiometer (MODIS) that can help develop biomass availability maps using remote sensing. To connect detailed ground measurements to coarse spatial resolution remotely sensed data from sources like AVHRR and MODIS, multi-scale images have been incorporated into biomass estimation methods and moderate spatial resolution images as a bridge between field data and coarser imagery [43-46].

The most widely used sources of remotely sensed images for forest biomass estimates have been the Landsat Thematic Mapper (TM) and Enhanced Thematic Mapper ETM+ data [39,40,42,47-49]. Several studies have used data from other moderate spatial resolution sensors to estimate forest biomass; these include ASTER [45], Hyperion [50], QuickBird [51], and IKONOS [52]. Remote sensing data offers the advantage of extended spatial coverage beyond that of national or state level biomass estimates from forest inventories [53]. Also, remotely sensed data can fill gaps in forest inventory data with attributes that allow biomass and carbon stock to be predicted with precision [54].

\subsubsection{Geographical Information System}

Biomass energy feedstock has the character of a geographically dependent energy resource [55]. A GIS is a tool that can be broadly used to estimate the biomass availability at a state or national level [56], and to investigate optimal logistics planning for minimal biomass transportation costs through a least-cost matrix [57]. Most GIS biomass estimation approaches have been based on the use of agriculture, forestry, economic, climate, reserved, and infrastructure data. Developed restriction and suitability models have been primarily used to define potential biomass availability and areas for collecting potential forest harvest residues.

Woo et al. [35] investigated biomass availability in Tasmania using integrated GIS, analytical hierarchy process (AHP), and multi-criteria analysis (MCA) techniques. The potential biomass availability was estimated based on the non-industrial private native forest (NIPNF) model in Tasmania. The optimal locations for prospective biomass power plants were identified using integrated MCA and GIS network analysis models including a supply chain cost analysis. Also, Delivand et al. [58] investigated optimal locations for bioenergy facilities and biomass potential through an integrated approach combining GIS with MCA. To investigate the optimal location of biomass facilities, minimized logistics costs and the corresponding life-cycle greenhouse gas (GHG) emissions were estimated. The potential biomass availability was investigated in three consecutive steps: land availability, land suitability, and location-allocation of biomass plants.

\subsubsection{Biomass Estimation Model}

There is a requirement for accurate biomass estimation methods at the national level. A combination of allometric equations and forest inventory data models such as EVALIDator, NIPNF, and FIA DataMart tools have been investigated for the estimation of the national level of forest residue and biomass availability in many countries [59-67].

Peltola et al. [68] have investigated the recovery rates of logging residue recovered from Norway spruce (Picea abies (L.) Karsten) dominated stands. The dry weight of logging residue was measured at a biomass plant location to estimate potential biomass availability at the stand level. The dry weights 
were calculated using biomass models developed for individual trees by Repola et al. [69]. The results from Repola's model were compared with Swedish biomass models produced by Marklund [70]. Peltola et al. [68] have found that the average recovery rates are slightly different between different models; however, the variation between the logging residue collection sites was high. This study highlighted that at least a third of the residue remained on the harvesting sites after collection.

Berg et al. [71] investigated variability in residue ratios, comparing growing stock residue volume to mill-delivered volume to better estimate residue production in the US. This study adopted model-based sampling to estimate the growing stock logging residue ratio for a multiple-state region and developed models that relate the residue ratio to individual tree and stand-level variables. The predictive residue estimation model was developed in relation to tree and site-level variables. The study result showed that the residue ratios were predicted to increase with the larger small-end diameter and decline exponentially with increasing diameter breast height (DBH). Ratios were predicted to drop when pulp logs were removed and when timber was mechanically felled. However, these estimation models are highly influenced by assumptions, and they are difficult to apply at the operating level of the biomass supply chain.

\subsubsection{Field Data Measurement}

Logging residue has been estimated at forest harvesting field sites. Logging residues are classified based on criteria such as the form of storage, residue scattering patterns, and type of materials. On site, residue is mainly divided into staking piles or scattered [72-74]. Hardy [75] investigated guidelines for estimating forest residue stacked piles volume in various pile shapes. The shapes of forest residue piles are classified into five generalized pile formats: half-sphere, paraboloids, half-cylinder, half frustum of a cone, half frustum of a cone with rounded ends, half-ellipsoid, and irregular solid as illustrated in Figure 1 [75]. Volumetric formulas were developed and used to estimate the gross volume of stacked piles.

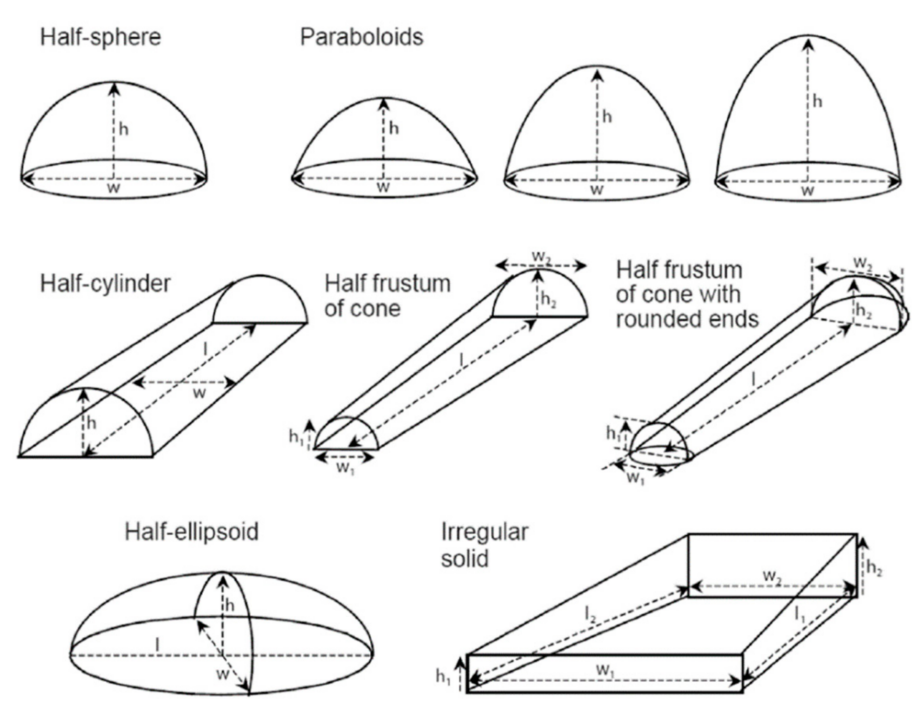

Figure 1. Generalized forest residue pile shape classification (Source: Hardy [75] copyright by Guidelines for estimating volume, biomass, and smoke production for piled slash. Gen. Tech. Rep. PNW-GTR-364. Portland, OR: U.S. Department of Agriculture, Forest Service, Pacific Northwest Research Station. 28 p.).

In scattered harvesting sites, the most commonly used logging residue estimation method is the line-intersect sampling (LIS) technique from the coarse woody debris inventory sampling method [76]. Warren and Olsen [77] introduced the LIS technique to estimate the logging residue volume in harvested forest sites. Kizha and Han [24] estimated the amount of forest residue recovered from whole-tree harvesting sites in Northern California. Pre- and post-harvest downed woody debris (DWD) techniques 
(line-intersect sampling) were applied to estimate the total amount of AGB in the harvesting sites. Localized allometric equations were used to estimate pre-harvest AGB. This study revealed that the recovered residue delivered as logging residue biomass feedstock from a ground-based harvesting system showed a high biomass recovery rate ( $70 \%$ for a shovel logged unit) compared with a cable yarding system ( $60 \%$ for a cable yarded unit).

\subsubsection{Limitations and Opportunities for Logging Residue Estimation Methods}

From the literature review, the most accurate method for estimating timber biomass is the direct destructive method. The direct destructive method involves the harvesting of a tree and measuring the weight of the different tree components (branches, leaves, trunk, etc.) including LIS and DWD techniques. However, the destructive method is time-consuming and has limited application at the national and state level [78].

Indirect methods such as applying allometric equations combined with modeling approaches allow the prediction of tree and residue volume at the state and national levels with some accuracy [64]. Identified opportunities and limitations of logging residue estimations are summarized in Table 1.

Table 1. Identified opportunities and limitations of forest feedstock availability models.

\begin{tabular}{|c|c|c|c|c|}
\hline $\begin{array}{l}\text { Estimation } \\
\text { Techniques }\end{array}$ & Remote Sensing & GIS & Modeling Approaches & $\begin{array}{l}\text { Destructive Field } \\
\text { Measurement }\end{array}$ \\
\hline Required data & $\begin{array}{l}\text { - } \quad \text { Remotely sensed } \\
\text { images (e.g., } \\
\text { MODIS, AVHRR) }\end{array}$ & $\begin{array}{l}\text { - Geospatial data } \\
\text { (e.g., forest } \\
\text { inventory map, and } \\
\text { infrastructural map) }\end{array}$ & $\begin{array}{l}\text { - } \quad \text { Regression model } \\
\text { based on } \\
\text { destructive field } \\
\text { measurement data }\end{array}$ & $\begin{array}{l}\text { - Field } \\
\text { site measurement }\end{array}$ \\
\hline $\begin{array}{l}\text { Opportunities of } \\
\text { the models }\end{array}$ & $\begin{array}{l}\text { Fill the gaps in } \\
\text { forest inventory } \\
\text { data with spatial, } \\
\text { attributional, } \\
\text { and temporal }\end{array}$ & $\begin{array}{l}\text { Investigate optimal } \\
\text { logistic planning } \\
\text { Integrated with } \\
\text { decision } \\
\text { support techniques }\end{array}$ & $\begin{array}{l}\text { High accuracy in } \\
\text { specific species } \\
\text { and locations }\end{array}$ & - $\quad$ The most accuracy \\
\hline
\end{tabular}

The foregoing limitations can be overcome the ICT technologies integrated into current harvesting equipment. Forest harvesters and processors are equipped with onboard computers and sensors, and these systems can generate data during harvesting operations called StanForD. This automated data collection system collects data such as DBH, length of a cut tree, and geo-coordinate information (longitude and latitude) with individual tree level. Integrated Standard for Forest machine Data (StanForD) compliant data and allometric equations (modeling) can predict harvesting productivity and residue volume with high precision [79]. The StanForD based logging residue estimation technique has been enhanced to develop biomass availability maps in near real-time and with improved data accuracy. The accumulation of estimated logging residue data can enable a forest manager or a biomass facilities manager to improve their management plan.

Additionally, unmanned aircraft systems (UAS) have been introduced to estimate coarse woody debris (CWD) in biomass harvested sites. The UAS technique not only decreases operational costs, but also takes less time than traditional CWD estimation methods [80]. UAS surveillance results indicated that its residue estimates are more accurate than line intercept sampling ground measurement and its data collection and analysis is much quicker than traditional sampling methods. For slash piles, drone-based estimation was lower than ground-based estimates. Despite underestimation issues, 
a UAS can contribute to decreasing operation costs and fieldwork time with additional calibration and correction.

\section{Secondary Forest Resources}

\subsection{Wood Processing Mill Residues}

The wood processing industry manufactures structural wood products such as lumber and plywood using roundwood or sawlogs. During the wood processing, tons of residue is produced by timber mills. Mill residues are being used to produce bioenergy and bio-based forest products through processes that enhance the value of this material that has traditionally been thought of as waste.

Sawmill residues consist of different types and shapes of material including bark, chips, chunks, offcuts, slabs, and fine material such as shavings and sawdust [81-83]. The residues are generally traded as mulch, firewood, hog fuel, animal bedding, engineered wood products (EWPs), and raw material for the pulp industry $[84,85]$.

As stated previously, one of the challenges in developing valuable material from forest residue is to quantify the amounts that are available to match the required input standards of each of the various biomass conversion processes [86,87]. The estimation of processing residues in the biomass industry is a challenge because the residue is generated as a by-product of sawmill operations and the availability of residue largely depends on the type of mill and its techniques [83,87]. Additionally, recovery rates vary depending on the processed species, equipment configuration, log quality, sawing methods, grading, storage, drying, and level of horizontal and vertical integration [88].

\subsubsection{Computational Methodology}

Generally, sawmill residue estimation is calculated by using volume and weight factors developed from literature and research [89]. Sawmills have different timber recovery factors depending on DBH, length, taper, and quality; sawing configuration, green mill processing quality, and size of dry-dressed lumber and kerf width [90]. Figure 2 shows where sawmill residue is generated in the sawmill processing chain.

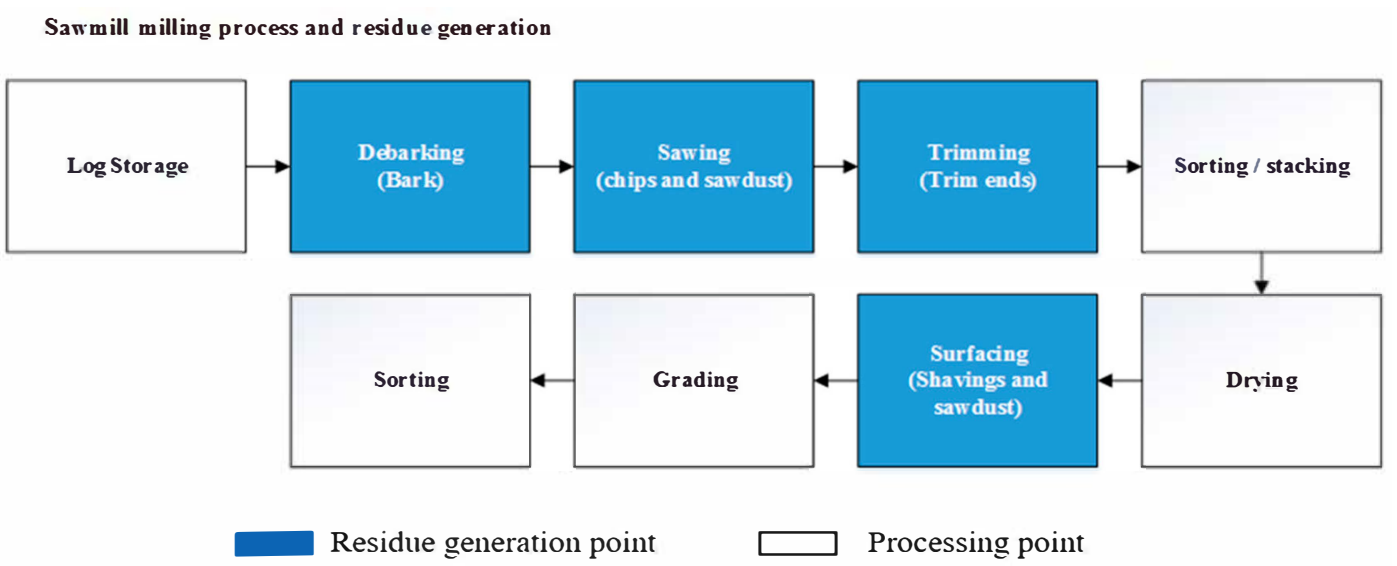

Figure 2. Map of sawmill residue generation in each milling processing.

Sawmill residue production rates are highly dependent on sawmilling technology, timber processing rate, price of mill residue products, and the options for residue utilization [91]. There are several methods for estimating processing mill residue availability. In California, U.S., mill residue production was estimated using sawmill residue volume and weight factors that were developed from literature and survey data under specific conditions and in specific years. The volume factor was defined as the dry volume of residue per cubic meter of processed sawlogs; the weight factor was the ratio of the dry weight of residue produced to the dry weight of processed sawlogs [92]. The general information and statistical data for timber harvest and sawlogs processing production in the California 
forest products industry were collected from published literature and reports $[93,94]$. The residue amounts were calculated based on the average generation rate for U.S conventional harvested timber considering only one general type of sawmill operation for the estimates [92]. Setzer [82] investigated a number of estimates of plant residues in the western U.S. In this research, most of the studies were focused on softwood species and estimated residue from veneer and plywood mills located in Colorado, Idaho, and Montana. The lumber mill portion of the residue was derived by subtracting veneer and plywood mill residue estimates from the total mill residue estimate. The recovery factor for $9.53 \mathrm{~mm}$ thick plywood was $4.92 \mathrm{~kg} / \mathrm{m}^{2}$ [95] and for veneer was $53 \mathrm{~m}^{2} / \mathrm{m}^{3}$ of $\log$ [96].

\subsubsection{Survey}

In Australia, wood processing mill residue comes primarily from the sawing and peeling mill industries. Data for wood processing residues were collected and reviewed; the data were from Australian national-level data sources, primarily the Australian Bureau of Agricultural and Resource Economics and the Department of Agriculture and Water Resources. The most recent assessment of the Tasmanian processing residue sector is a survey completed in 2013 [97]. The survey results provide the best estimate of current levels of mill processing residue in Tasmania. The survey estimation was compiled from oral and written interviews with representatives of the wood processing industry from May to June, 2013 [98]. During the survey period, the participating companies processed more than $90 \%$ of the total milling output in Tasmania.

Information and data about the amount of processed timber, processing residue generation, current use of residues, and potential residue availability were discussed and gathered during the interview process. The percentage of processing residue generation and potential biomass energy availability were estimated separately for two different milling types and two different product types: softwood sawmill, hardwood sawmill, softwood chipping, and hardwood chipping [99]. Domestic firewood consumption and production were estimated by Driscoll et al. [100] and Todd [101]; unpublished data from a wood-heater survey conducted by the Tasmanian Environment Protection Authority during the winter of 2011 were investigated [99].

\section{Discussion}

Increased fuel costs and environmental concerns have contributed to the rise of renewable energy sources as alternatives to fossil fuel. As a source of renewable energy, forest biomass is considered to be an important resource in many countries.

Forest residues, the by-products of conventional timber harvesting including small-diameter trees, tops, limbs, and chunks, provide an opportunity to produce bioenergy and bio-based forest products in a more carbon-positive way [35]. Many countries are already using residues to successfully produce an alternative to fossil fuel and reduce carbon emissions. New technologies applied to combustion, gasification, palletization, pyrolysis, briquettes, and torrefaction are able to convert forest residues into high quality and sustainable bioenergy and bio-based materials [102,103].

However, based on international and local research into forest residue utilization, it is evident that several challenges must be addressed to ensure residues can be used for valuable bioenergy feedstock. In particular, The uncertainty of biomass availability can increase the risk of wrong decision making in the biomass supply chain $[4,104,105]$.

In this context, this paper reviews assessment techniques in forest biomass energy resources along the timber supply chain. At the primary forest resource, the majority of studies have estimated forest biomass using remote sensing [36,37], GIS techniques [56], and modeling approaches [59-67] at the state level. Remote sensing and GIS studies have been useful to provide large-scale insights into biomass availability under different geographical and environmental conditions. However, they cannot provide highly accurate biomass availability estimates. On the other hand, field data collection, the most accurate method of biomass estimation, has limited utility for large scale biomass estimation. 
Fortunately, forest machines with integrated ICT systems have been investigated and are coming online to improve the accuracy of forest inventory data for large scale estimates of biomass availability. Also, UAS technology has been introduced to measure biomass availability with reduced cost and time. Given the rising public awareness of bioenergy, a precise biomass estimation tool to support biomass industries is needed to make the most efficient use of biomass resources.

In the literature on secondary forest resources, limitations and challenges were identified in processing mill residue estimating. Biomass recovery rates differ according to sawmill configuration, species processed, log quality, and other factors $[83,87]$. Currently, secondary forest resources are estimated using computational methods and surveys. These techniques provide reliable information about processing residue availability, but the resulting data and information can be exposed to a high risk of contamination from human intervention. Further research is needed to investigate automated data capturing systems to improve processing mill residue collection. There is also a need to develop an integrated ICT biomass estimation system that automatically collects data at the mill.

\section{Conclusions}

This paper presents a summary review of forest and woody residue estimation methods and techniques along the wood supply chain. The report examines both the opportunities and the challenges evident in international forest residue estimation methods. The review reveals that many estimation methods have been adapted and have improved logging residue estimation. Currently, integrated ICT systems are being implemented to improve the accuracy of residue estimation. However, wood processing residue estimation has multiple challenges in estimating biomass availability. There is still a need for future research into accurate and economical forest residue estimation, especially in wood processing mill residues. This literature review was prepared for the primary use of stakeholders aligned with forest biomass energy utilization. It is however, anticipated that it will also be useful for other organizations and researchers working in this or related fields in globally.

Author Contributions: Conceptualization, H.W. and J.P.; Methodology, H.W.; Validation, H.W., J.P. and M.A.; Formal Analysis, H.W.; Investigation, H.W.; Resources, H.W. and S.C.; Data Curation, H.W., M.A., S.C., and J.P.; Writing-Original Draft Preparation, H.W.; Writing-Review \& Editing, H.W., J.P., and M.A.; Visualization, H.W., Project Administration, J.P.; Funding Acquisition, J.P. Authorship must be limited to those who have contributed substantially to the work reported.

Funding: This research used in this paper was funded through the Korea Forest Service (Korea Forestry Promotion Institute) project called: R\&D Program for Forest Science Technology (Project No. 2019149C10-1923-0301).

Conflicts of Interest: The authors declare no conflict of interest.

\section{References}

1. European Union. Communication from the Commission to the European Parliament, the Council, the European Economic and Social Committee and the Committee of the Regions; European Union: Brussels, Belgium, 2014.

2. European Biomass and Association. European Bioenergy Outlook 2012. Available online: http://www. aebiom.org (accessed on 15 August 2014).

3. Mantau, U.; Saal, U.; Prins, K.; Steierer, F.; Lindner, M.; Verkerk, H.; Eggers, J.; Leek, N.; Oldenburger, J.; Asikainen, A. Real Potential for Changes in Growth and Use of EU Forests; EUwood. Final report; University of Hamburg Centre of Wood Science: Hamburg, Germany, 2010.

4. Perlack, R.D. Biomass as Feedstock for a Bioenergy and Bioproducts Industry: The Technical Feasibility of a Billion-ton Annual Supply; Oak Ridge National Laboratory: Oak Ridge, TN, USA, 2005.

5. McKendry, P. Energy production from biomass (part 1): Overview of biomass. Bioresour. Technol. 2002, 83, 37-46. [CrossRef]

6. Sedjo, R.A. The economics of forest-based biomass supply. Energy Policy 1997, 25, 559-566. [CrossRef]

7. Tillman, D.; Duong, D.; Harding, N. Chapter 4-Blending Coal with Biomass: Cofiring Biomass with Coal. In Solid Fuel Blending; Butterworth-Heinemann: Boston, MA, USA, 2012; pp. 125-200.

8. FAO. Unified Bioenergy Terminology; FAO: Rome, Italy, 2012. 
9. Cambero, C.; Sowlati, T. Assessment and optimization of forest biomass supply chains from economic, social and environmental perspectives-A review of literature. Renew. Sustain. Energy Rev. 2014, 36, 62-73. [CrossRef]

10. Shabani, N.; Akhtari, S.; Sowlati, T. Value chain optimization of forest biomass for bioenergy production: A review. Renew. Sustain. Energy Rev. 2013, 23, 299-311. [CrossRef]

11. Iakovou, E.; Karagiannidis, A.; Vlachos, D.; Toka, A.; Malamakis, A. Waste biomass-to-energy supply chain management: A critical synthesis. Waste Manag. 2010, 30, 1860-1870. [CrossRef]

12. Gold, S.; Seuring, S. Supply chain and logistics issues of bio-energy production. J. Clean. Prod. 2011, 19, 32-42. [CrossRef]

13. Sharma, B.; Ingalls, R.; Jones, C.; Khanchi, A. Biomass supply chain design and analysis: Basis, overview, modeling, challenges, and future. Renew. Sustain. Energy Rev. 2013, 24, 608-627. [CrossRef]

14. Scott, J.A.; Ho, W.; Dey, P.K. A review of multi-criteria decision-making methods for bioenergy systems. Energy 2012, 42, 146-156. [CrossRef]

15. Awudu, I.; Zhang, J. Uncertainties and sustainability concepts in biofuel supply chain management: A review. Renew. Sustain. Energy Rev. 2012, 16, 1359-1368. [CrossRef]

16. Mafakheri, F.; Nasiri, F. Modeling of biomass-to-energy supply chain operations: Applications, challenges and research directions. Energy Policy 2014, 67, 116-126. [CrossRef]

17. Yue, D.; You, F.; Snyder, S.W. Biomass-to-bioenergy and biofuel supply chain optimization: Overview, key issues and challenges. Comput. Chem. Eng. 2014, 66, 36-56. [CrossRef]

18. Ghaffariyan, M.R. Review of European biomass harvesting technologies. Silva Balc. 2010, 11, 5-20.

19. Ghaffariyan, M.R.; Brown, M.; Acuna, M.; Sessions, J.; Gallagher, T.; Kühmaier, M.; Spinelli, R.; Visser, R.; Devlin, G.; Eliasson, L.; et al. An international review of the most productive and cost effective forest biomass recovery technologies and supply chains. Renew. Sustain. Energy Rev. 2017, 74, 145-158. [CrossRef]

20. CEN/TS-16559. Solid Biofuels. Terminology, Definitions and Descriptions; European Standardisation Committee for Standardization: Brussels, Belgium, 2014; p. 32.

21. Routa, J.; Asikainen, A.; Björheden, R.; Laitila, J.; Röser, D. Forest energy procurement: State of the art in Finland and Sweden. Wiley Interdiscip. Rev. Energy Environ. 2013, 2, 602-613. [CrossRef]

22. Laitila, J.; Lehtonen, E.; Ranta, T.; Anttila, P.; Rasi, S.; Asikainen, A. Procurement costs of cereal straw and forest chips for biorefining in South-East Finland. Silva Fenn. 2016, 50, 50. [CrossRef]

23. Bisson, J.; Han, S.-K.; Han, H.-S. Evaluating the system logistics of a biomass recovery operation in northern California. For. Prod. J. 2016, 66, 88-96. [CrossRef]

24. Kizha, A.R.; Han, H.-S. Forest residues recovered from whole-tree timber harvesting operations. Eur. J. For. Eng. 2015, 1, 46-55.

25. McKechnie, J.; Colombo, S.; Chen, J.; Mabee, W.; MacLean, H.L. Forest bioenergy or forest carbon? Assessing trade-offs in greenhouse gas mitigation with wood-based fuels. Environ. Sci. Technol. 2010, 45, 789-795. [CrossRef]

26. Laganière, J.; Paré, D.; Thiffault, E.; Bernier, P.Y. Range and uncertainties in estimating delays in greenhouse gas mitigation potential of forest bioenergy sourced from Canadian forests. Gcb Bioenergy 2017, 9, 358-369. [CrossRef]

27. Mitchell, S.R.; Harmon, M.E.; O'connell, K.E. Carbon debt and carbon sequestration parity in forest bioenergy production. Gcb Bioenergy 2012, 4, 818-827. [CrossRef]

28. Bernier, P.; Paré, D. Using ecosystem $\mathrm{CO}_{2}$ measurements to estimate the timing and magnitude of greenhouse gas mitigation potential of forest bioenergy. Gcb Bioenergy 2013, 5, 67-72. [CrossRef]

29. Holtsmark, B. Harvesting in boreal forests and the biofuel carbon debt. Clim. Chang. 2012, 112, 415-428. [CrossRef]

30. Krajnc, N.; Domac, J. How to model different socio-economic and environmental aspects of biomass utilisation: Case study in selected regions in Slovenia and Croatia. Energy Policy 2007, 35, 6010-6020. [CrossRef]

31. Werhahn Mees, W.; Palosuo, T.; Garcia-Gonzalo, J.; RÖser, D.; Lindner, M. Sustainability impact assessment of increasing resource use intensity in forest bioenergy production chains. Gcb Bioenergy 2011, 3, 91-106. [CrossRef]

32. den Herder, M.; Kolström, M.; Lindner, M.; Suominen, T.; Tuomasjukka, D.; Pekkanen, M. Sustainability impact assessment on the production and use of different wood and fossil fuels employed for energy production in North Karelia, Finland. Energies 2012, 5, 4870-4891. [CrossRef] 
33. Andersen, H.-E.; Strunk, J.; Temesgen, H. Using airborne light detection and ranging as a sampling tool for estimating forest biomass resources in the Upper Tanana Valley of Interior Alaska. West. J. Appl. For. 2011, 26, 157-164. [CrossRef]

34. Huang, S.; Crabtree, R.L.; Potter, C.; Gross, P. Estimating the quantity and quality of coarse woody debris in Yellowstone post-fire forest ecosystem from fusion of SAR and optical data. Remote Sens. Environ. 2009, 113, 1926-1938. [CrossRef]

35. Woo, H.; Acuna, M.; Moroni, M.; Taskhiri, M.; Turner, P. Optimizing the location of biomass energy facilities by integrating Multi-Criteria Analysis (MCA) and Geographical Information Systems (GIS). Forests 2018, 9 , 585. [CrossRef]

36. Lu, D. The potential and challenge of remote sensing based biomass estimation. Int. J. Remote. Sens. 2006, 27, 1297-1328. [CrossRef]

37. Patenaude, G.; Milne, R.; Dawson, T.P. Synthesis of remote sensing approaches for forest carbon estimation: Reporting to the Kyoto Protocol. Environ. Sci. Policy 2005, 8, 161-178. [CrossRef]

38. Feng, X.; Liu, G.; Chen, J.; Chen, M.; Liu, J.; Ju, W.; Sun, R.; Zhou, W. Net primary productivity of Chinas terrestrial ecosystems from a process model driven by remote sensing. J. Environ. Manag. 2007, 85, 563-573. [CrossRef] [PubMed]

39. Luther, J.; Fournier, R.; Piercey, D.; Guindon, L.; Hall, R. Biomass mapping using forest type and structure derived from Landsat TM imagery. Int. J. Appl. Earth Obs. Geoinf. 2006, 8, 173-187. [CrossRef]

40. Zheng, G.; Chen, J.; Tian, Q.; Ju, W.; Xia, X. Combining remote sensing imagery and forest age inventory for biomass mapping. J. Environ. Manag. 2007, 85, 616-623. [CrossRef] [PubMed]

41. Hall, R.; Skakun, R.; Arsenault, E.; Case, B. Modeling forest stand structure attributes using Landsat ETM+ data: Application to mapping of aboveground biomass and stand volume. For. Ecol. Manag. 2006, 225, 378-390. [CrossRef]

42. Labrecque, S.; Fournier, R.; Luther, J.; Piercey, D. A comparison of four methods to map biomass from Landsat-TM and inventory data in western Newfoundland. For. Ecol. Manag. 2006, 226, 129-144. [CrossRef]

43. Wulder, M.A.; White, J.C.; Fournier, R.A.; Luther, J.E.; Magnussen, S. Spatially explicit large area biomass estimation: Three approaches using forest inventory and remotely sensed imagery in a GIS. Sensors 2008, 8, 529-560. [CrossRef] [PubMed]

44. Tomppo, E.; Nilsson, M.; Rosengren, M.; Aalto, P.; Kennedy, P. Simultaneous use of Landsat-TM and IRS-1C WiFS data in estimating large area tree stem volume and aboveground biomass. Remote Sens. Environ. 2002, 82, 156-171. [CrossRef]

45. Muukkonen, P.; Heiskanen, J. Biomass estimation over a large area based on standwise forest inventory data and ASTER and MODIS satellite data: A possibility to verify carbon inventories. Remote Sens. Environ. 2007, 107, 617-624. [CrossRef]

46. Hame, T.; Salli, A.; Andersson, K.; Lohi, A. A new methodology for the estimation of biomass of coniferdominated boreal forest using NOAA AVHRR data. Int. J. Remote. Sens. 1997, 18, 3211-3243. [CrossRef]

47. Meng, Q.; Cieszewski, C.J.; Madden, M.; Borders, B. A linear mixed-effects model of biomass and volume of trees using Landsat ETM+ images. For. Ecol. Manag. 2007, 244, 93-101. [CrossRef]

48. Foody, G.M. Remote sensing of tropical forest environments: Towards the monitoring of environmental resources for sustainable development. Int. J. Remote. Sens. 2003, 24, 4035-4046. [CrossRef]

49. GonzálezAlonso, F.; Merino-De-Miguel, S.; Roldán-Zamarrón, A.; García-Gigorro, S.; Cuevas, J. Forest biomass estimation through NDVI composites. The role of remotely sensed data to assess Spanish forests as carbon sinks. Int. J. Remote. Sens. 2006, 27, 5409-5415. [CrossRef]

50. Kalacska, M.; Sanchez-Azofeifa, G.A.; Rivard, B.; Caelli, T.; White, H.P.; Calvo-Alvarado, J.C. Ecological fingerprinting of ecosystem succession: Estimating secondary tropical dry forest structure and diversity using imaging spectroscopy. Remote Sens. Environ. 2007, 108, 82-96. [CrossRef]

51. Leboeuf, A.; Beaudoin, A.; Fournier, R.; Guindon, L.; Luther, J.; Lambert, M.-C. A shadow fraction method for mapping biomass of northern boreal black spruce forests using QuickBird imagery. Remote Sens. Environ. 2007, 110, 488-500. [CrossRef]

52. Proisy, C.; Couteron, P.; Fromard, F. Predicting and mapping mangrove biomass from canopy grain analysis using Fourier-based textural ordination of IKONOS images. Remote Sens. Environ. 2007, 109, 379-392. [CrossRef] 
53. Fournier, R.; Luther, J.; Guindon, L.; Lambert, M.-C.; Piercey, D.; Hall, R.; Wulder, M. Mapping aboveground tree biomass at the stand level from inventory information: Test cases in Newfoundland and Quebec. Can. J. For. Res. 2003, 33, 1846-1863. [CrossRef]

54. Birdsey, R. Data gaps for monitoring forest carbon in the United States: An inventory perspective. Environ. Manag. 2004, 33, S1-S8. [CrossRef]

55. Sultana, A.; Kumar, A. Optimal siting and size of bioenergy facilities using geographic information system. Appl. Energy 2012, 94, 192-201. [CrossRef]

56. Beccali, M.; Columba, P.; D’Alberti, V.; Franzitta, V. Assessment of bioenergy potential in Sicily: A GIS-based support methodology. Biomass Bioenergy 2009, 33, 79-87. [CrossRef]

57. Montgomery, T.D.; Han, H.-S.; Kizha, A.R. Modeling work plan logistics for centralized biomass recovery operations in mountainous terrain. Biomass Bioenergy 2016, 85, 262-270. [CrossRef]

58. Delivand, M.K.; Cammerino, A.R.B.; Garofalo, P.; Monteleone, M. Optimal locations of bioenergy facilities, biomass spatial availability, logistics costs and GHG (greenhouse gas) emissions: A case study on electricity productions in South Italy. J. Clean. Prod. 2015, 99, 129-139. [CrossRef]

59. Morgan, T.A. An Assessment of Forest-Based Woody Biomass Supply and Use in Montana; Montana Department of Natural Resources and Conservation: Helena, MT, USA, 2009.

60. Service, U.F. All live trees on forest land by species group and diameter class (in cubic feet). In Forest Inventory and Analysis National Program; US Department of Agriculture, Forest Service, Pacific Northwest Research Station: Portland, OR, USA, 2014.

61. PFT. Residue Solution Project; Private forests Tasmania: Hobart, Australia, 2014.

62. Raison, R.; Kirschbaum, M.; McCormack, R.; Attiwill, P.; Richardson, A. Review of the Science Relevant to the Sustainable Use of Native and Plantation Forest-Harvesting Residues for Energy Production in Tasmania; CSIRO Forestry and Forest Products: Canberra, Australia, 2002.

63. Wilson, J. Private Forest Resourcing Model 2012: Where Are the Best Locations for a Hypothetical Tasmanian Wood Processing Plant, Unpublished Report of Esk Mapping \& GIS to Private Forests Tasmania. 2012.

64. Cutini, A.; Chianucci, F.; Manetti, M.C. Allometric relationships for volume and biomass for stone pine (Pinus pinea L.) in Italian coastal stands. IFor-Biogeosci. For. 2013, 6, 331. [CrossRef]

65. Eamus, D.; Burrows, W.; McGuinness, K. Review of Allometric Relationships for Estimating Woody Biomass for Queensland, the Northern Territory and Western Australia; Australian Greenhouse Office: Canberra, Australia, 2000.

66. Fehrmann, L.; Kleinn, C. General considerations about the use of allometric equations for biomass estimation on the example of Norway spruce in central Europe. For. Ecol. Manag. 2006, 236, 412-421. [CrossRef]

67. Keith, H.; Barrett, D.; Keenan, R. Review of Allometric Relationships for Woody Biomass for NSW, ACT, VIC, TAS, SA; National Carbon Accounting Technical Report No. 5b; Australian Greenhouse Office: Canberra, Australia, 1999.

68. Peltola, S.; Kilpeläinen, H.; Asikainen, A. Recovery rates of logging residue harvesting in Norway spruce (Picea abies (L.) Karsten) dominated stands. Biomass Bioenergy 2011, 35, 1545-1551. [CrossRef]

69. Repola, J.; Ojansuu, R.; Kukkola, M. Biomass Functions for Scots Pine, Norway Spruce and Birch in Finland; Finnish Forest Research Institute: Helsinki, Finland, 2007.

70. Marklund, L.G. Biomass Functions for Pine, Spruce and Birch in Sweden; The Swedish University for Agricultural Sciences: Uppsala, Sweden, 1988.

71. Berg, E.C.; Morgan, T.A.; Simmons, E.A.; Zarnoch, S.J.; Scudder, M.G. Predicting logging residue volumes in the Pacific Northwest. For. Sci. 2016, 62, 564-573. [CrossRef]

72. Kizha, A.R.; Han, H.-S. Moisture content in forest residues: An insight on sampling methods and procedures. Curr. For. Rep. 2017, 3, 202-212. [CrossRef]

73. Filbakk, T.; Høibø, O.; Nurmi, J. Modelling natural drying efficiency in covered and uncovered piles of whole broadleaf trees for energy use. Biomass Bioenergy 2011, 35, 454-463. [CrossRef]

74. Nurmi, J. The storage of logging residue for fuel. Biomass bioenergy 1999, 17, 41-47. [CrossRef]

75. Hardy, C.C. Guidelines for Estimating Volume, Biomass, and Smoke Production for Piled Slash; General Technical Report PNW-GTR-364; US Department of Agriculture, Forest Service, Pacific Northwest Research Station: Portland, OR, USA, 1998; 28p.

76. Oneil, E.; Lippke, B. Eastern Washington Biomass Accessibility; University of Washington: Seattle, WA, USA, 2009. 
77. Warren, W.; Olsen, P. A line intersect technique for assessing logging waste. For. Sci. 1964, 10, 267-276.

78. Vashum, K.T.; Jayakumar, S. Methods to estimate above-ground biomass and carbon stock in natural forests-a review. J. Ecosyst. Ecogr. 2012, 2, 1-7. [CrossRef]

79. Heesung Woo, M.S.T.; Turner, P. Optimising forest residue utilization in bio-energy value chains: A case study integrating data analytics and real-time forestry biomass monitoring. Biomass Bioenergy 2019, in press.

80. Davis, B.J. Refinement of a Drone-Based Method for Estimating Coarse Woody Debris and Biomass Residue Following Forest Harvest. Ph.D. Thesis, University of Georgia, Athens, GA, USA, 2017.

81. Walsh, M.E.; Perlack, R.L.; Turhollow, A.; de la Torre Ugarte, D.; Becker, D.A.; Graham, R.L.; Slinsky, S.E.; Ray, D.E. Biomass Feedstock Availability in the United States: 1999 State Level Analysis; EERE Publication and Product Library: Washington, DC, USA, 2000.

82. Setzer, T.S. Estimates of Timber Products Output and Plant Residues, Arizona, 1969; United States Department of Agriculture, Forest Service, Intermountain: Ogden, UT, USA, 1971; Volume 130.

83. Rosillo-Calle, F.; Woods, J. The Biomass Assessment Handbook; Routledge: Abingdon, UK, 2012.

84. Bradley, D. Canada Report on Bioenergy 2010; Climate Change Solutions: Ottawa, ON, Canada, 2010.

85. Fonseca, M.A. The Measurement of Roundwood: Methodologies and Conversion Ratios; CABI: Wallingford, UK, 2005.

86. McKeever, D.B. Inventories of woody residues and solid wood waste in the United States, 2002. In Proceedings of The Ninth International Conference on Inorganic-Bonded Composite Materials Conference, Vancouver, BC, Canada, 10-13 October 2004.

87. Kehbila, A.T. Evaluation of Primary Wood Processing Residues for Bioenergy in British Columbia; University of British Columbia: Vancouver, BC, Canada, 2010.

88. Goble, D.; Jarvis, C. Opportunities for Using Sawmill Residues in Australia; Forest \& Wood Products Australia: Melbourne, Australia, 2007.

89. Kizhakkepurakkal, A.R. Opportunities and Challenges Associated with Development of Wood Biomass Energy Production in Louisiana. Master's Thesis, Louisiana State University, Baton Rouge, LA, USA, 2008.

90. Steele, P.H. Factors Determining Lumber Recovery in Sawmilling; Forest Products Lab: Madison, WI, USA, 1984.

91. Keegan, C.; Blatner, K.; Wichman, D.P. Changing Use Patterns by Major Users of Mill Residue in the Inland Northwest. For. Prod. J. 1999, 49, 34-37.

92. Yang, P.; Jenkins, B. Wood residues from sawmills in California. Biomass Bioenergy 2008, 32, 101-108. [CrossRef]

93. Warren, D.D. Production, Prices, Employment, and Trade in Northwest Forest Industries, All Quarters 2003; DIANE Publishing: Collingdale, PA, USA, 2005.

94. Warren, D.D. Production, Prices, Employment, and Trade in Northwest Forest Industries, All Quarters 2004; Resource Bulletin PNW-RB-250; US Department of Agriculture, Forest Service, Pacific Northwest Research Station: Portland, OR, USA, 2006; 165p.

95. Keegan, C.E. Idahos Forest Products Industry: A Descriptive Analysis, 1985; Bureau of Business and Economic Research, University of Montana: Missoula, MT, USA, 1988.

96. Hartman, D.A. Conversion Factors the Pacific Northwest Forest Industry: Converting Forest Growth To Forest Products; University of Washington: Seattle, WA, USA, 1976.

97. URS. Stage 1-Residue Options Identification and Analysis; URS-Report; URS: Adelaide, Australia, 2015.

98. Rothe, A. Forest Biomass for Energy: Current and Potential Use in Tasmania and a Comparison with European Experience; Weihenstephan-Triesdorf University of Applied Sciences (Hochschule Weihenstephan-Triesdorf): Freising, Germany, 2013.

99. Rothe, A.; Moroni, M.; Neyland, M.; Wilnhammer, M. Current and potential use of forest biomass for energy in Tasmania. Biomass Bioenergy 2015, 80, 162-172. [CrossRef]

100. Driscoll, D.; Freudenberger, D.; Milkovits, G. Impact and Use of Firewood in Australia; CSIRO Sustainable Ecosystems Canberra: Canberra, Australia, 2000.

101. Todd, J. Residential firewood estimates for Tasmania. Hobart: Eco-Energy Options Pty Ltd. 2013; [unpublished].

102. Han, H.-S.; Jacobson, A.; Bilek, E.T.; Sessions, J. Waste to Wisdom: Utilizing forest residues for the production of bioenergy and biobased products. Appl. Eng. Agric. 2018, 34, 5-10. [CrossRef]

103. Woo, H.; Han, H.-S. Performance of screening biomass feedstocks using star and deck screen machines. Appl. Eng. Agric. 2018, 34, 35-42. [CrossRef] 
104. Francois Cramer, M.F.; Gray, M.; Jaraczewski, S.; Kuster, J.; Shanker, P.; Vempati, A.R.; Wayne, C.; Wisbeski, L. Feasibility Report for Biomass Energy Plant In Berlin, New York; Columbia University: New York, NY, USA, 2016.

105. Burak, A.; Harry, C.; David, W.; Kevin, G.; Sujith, S.; Mario, E.; Norman, S. Woody biomass and mill waste utilization opportunities in Alabama: Transportation cost minimization, optimum facility location, economic feasibility, and impact. Environ. Prog. Sustain. Energy 2011, 30, 720-732. [CrossRef]

(C) 2019 by the authors. Licensee MDPI, Basel, Switzerland. This article is an open access article distributed under the terms and conditions of the Creative Commons Attribution (CC BY) license (http://creativecommons.org/licenses/by/4.0/). 